\title{
Parameterization of black carbon aging in the OsloCTM2 and implications for regional transport to the Arctic
}

\author{
M. T. Lund ${ }^{1}$ and T. Berntsen ${ }^{1,2}$ \\ ${ }^{1}$ CICERO - Center for International Climate and Environmental Research, Oslo, Norway \\ ${ }^{2}$ Department of Geosciences, University of Oslo, Oslo, Norway
}

Correspondence to: M. T. Lund (m.t.lund@cicero.uio.no)

Received: 24 November 2011 - Published in Atmos. Chem. Phys. Discuss.: 9 December 2011

Revised: 2 April 2012 - Accepted: 21 July 2012 - Published: 3 August 2012

\begin{abstract}
A critical parameter for the atmospheric lifetime of black carbon (BC) aerosols, and hence for the range over which the particles can be transported, is the aging time, i.e. the time before the aerosols become available for removal by wet deposition. This study compares two different parameterizations of $\mathrm{BC}$ aging in the chemistry transport model OsloCTM2: (i) A bulk parameterization (BULK) where aging is represented by a constant transfer to hydrophilic mode and (ii) a microphysical module (M7) where aging occurs through particle interaction and where the particle size distribution is accounted for. We investigate the effect of including microphysics on the distribution of BC globally and in the Arctic. We also focus on the impact on estimated contributions to Arctic BC from selected emission source regions. With more detailed microphysics (M7) there are regional and seasonal variations in aging. The aging is slower during high-latitude winter, when the production of sulfate is lower, than in lower latitudes and during summer. Highlatitude concentrations of BC are significantly increased during winter compared to BULK. Furthermore, M7 improves the model performance at Arctic surface stations, especially the accumulation of $\mathrm{BC}$ during winter. A proper representation of vertical BC load is important because the climate effects of the aerosols depend on their altitude in the atmosphere. Comparisons with measured vertical profiles indicate that the model generally overestimates the BC load, particularly at higher altitudes, and this overestimation is exacerbated with M7 compared to BULK. Both parameterizations show that north of $65^{\circ} \mathrm{N}$ emissions in Europe contribute most to atmospheric $\mathrm{BC}$ concentration and to $\mathrm{BC}$ in snow and ice. M7 leads to a pronounced seasonal pattern in contributions and contributions from Europe and Russia increase strongly
\end{abstract}

during winter relative to BULK. There is generally an increase in the amount of $\mathrm{BC}$ in snow and ice with M7 compared to BULK. However, in regions where the concentration of BC in snow is strongly underestimated with BULK compared to measurements, this increase with M7 is not sufficient to significantly improve the comparison.

\section{Introduction}

Black carbon (BC) aerosols have received increasing attention as a contributor to climate warming. BC can contribute to temperature change through several mechanisms; absorption of direct and reflected solar radiation (Haywood and Shine, 1997; Jacobson, 2002; Myhre et al., 2009; Schulz et al., 2006; Skeie et al., 2011), impacts on cloud cover and formation (Ackerman et al., 2000; Cook and Highwood, 2004; Johnson et al., 2004; Koch et al., 2011; Koren et al., 2004; Liu et al., 2009; Penner et al., 2009) and reduction of the surface albedo when deposited on snow and ice (Clarke and Noone, 1985; Flanner et al., 2009; Flanner et al., 2007; Hansen and Nazarenko, 2003; Jacobson, 2004; Rypdal et al., 2009b; Warren and Wiscombe, 1980)

The short atmospheric lifetime of BC means that emission reductions will have a rapid response and reduction of $\mathrm{BC}$ emissions may be an efficient way of slowing down global warming, especially at high latitudes (Bond, 2007; Bond and Sun, 2005; Hansen et al., 2000; Jacobson, 2002; Kopp and Mauzerall, 2010; Quinn et al., 2008). Such reductions would also have significant co-benefits for air pollution and health (Aunan et al., 2006; Jacobson, 2010; Rypdal et al., 2009a). The implementation of an efficient policy aimed at 
$\mathrm{BC}$, which is currently not regulated under any global agreements, requires knowledge of where measures are economically and politically most feasible and where the effect on climate is most beneficial (Rypdal et al., 2009b). Studies have shown that the radiative forcing and the potential for long-range transport can depend on the location of emissions (Berntsen et al., 2006; Koch et al., 2007; Reddy and Boucher, 2007; Shindell and Faluvegi, 2009; Shindell et al., 2008), especially for a short-lived and spatially heterogeneous component such as BC, due to regional differences in meteorological conditions, radiative properties and deposition pathways. The same abatement in one region can thus give greater reduction in global mean temperature change than in other regions. With a particular focus on abatements leading to reduced $\mathrm{BC}$ concentrations in snow and ice in the Arctic region it is important to quantify the regional and sectoral contributions to Arctic pollution (AMAP, 2011).

The main sink of $\mathrm{BC}$ aerosols is wet deposition. A large fraction of the emitted $\mathrm{BC}$ aerosols are initially hydrophobic and thus not easily removed by precipitation. Aging is the process through which particles become available for wet deposition, and the aging time is therefore a crucial parameter for the atmospheric lifetime, transport and distribution. Slow aging leads to less efficient removal, a longer lifetime and higher burden. Aging also leads to the formation of internally mixed particles, which has consequences for the optical properties through increasing the absorption (Bauer et al., 2010; Bond and Bergstrom, 2006; Jacobson, 2001; Schwarz et al., 2008). Particles are aged through condensation of soluble material such as sulfuric and nitric acid onto the aerosols, through coagulation with more soluble species and through oxidation (Vignati et al. (2010) and references therein). The aging time is expected to vary regionally depending on the availability of soluble species and on local atmospheric conditions. Studies have shown that the modelled distribution of black carbon depends significantly on the treatment of aging. In particular, inclusion of seasonally and regionally varying aging times affect concentrations at high latitudes (Bauer et al., 2010; Croft et al., 2005; Koch, 2001; Liu et al., 2011).

Here we use the chemistry transport model OsloCTM2 to study the transport and deposition of BC using two different parameterizations of aging. The first is a traditional bulk parameterization where only total mass of $\mathrm{BC}$ is included and aging is represented by a constant transfer to the hydrophilic mode, given by an exponential decay of 1.15 days (Cooke et al., 1999). This is a quite crude simplification as possible temporal and spatial variations are ignored. The second parameterization is the module for aerosol microphysics called M7 (Vignati et al., 2004), which has been implemented in the OsloCTM2 to represent particle size distribution, aging and growth through particle interaction and the formation of mixed particles. This study compares results from these aerosol parameterizations with two objectives: To investigate (i) the general effect of the parameterizations on transport, distribution and lifetime of $\mathrm{BC}$ and (ii) the effect on trans- port to and deposition in the Arctic from selected emission source regions. Section 2 describes the model and BC parameterizations, while results are presented and discussed in Sect. 3. Section 4 gives conclusions and suggestions for further work.

\section{Model and method}

\subsection{The OsloCTM2}

The OsloCTM2 is a global 3-dimensional model with transport driven by meteorological data from the European Centre of Medium Range Weather Forecasts (ECMWF) (Berglen et al., 2004; Berntsen et al., 2006; Myhre et al., 2009; Skeie et al., 2011). The advection of chemical species is calculated by the second order moment method (Prather, 1986). Vertical mixing is based on Tiedtke (1989) and turbulent mixing in the boundary layer is treated according to the Holtslag Kprofile scheme (Holtslag et al., 1990). The chemistry scheme is solved using the quasi steady state approximation (QSSA) (Berntsen and Isaksen, 1997). In this study, the horizontal resolution is $2.8^{\circ} \times 2.8^{\circ}$, with 40 vertical layers. The model is run for 18 months using year 2005/2006 meteorology and the first 6 months are discarded as spin-up. A number of simulations are performed. For both BC parameterizations, a reference simulation with all emissions and simulations for four separate emission source regions (Europe, China, North America and Russia including former USSR) are done. We focus on regional contributions of fossil fuel and biofuel BC. Emissions from open biomass burning sources are more difficult to regulate and the $\mathrm{OC} / \mathrm{BC}$ ratio is higher (Bice et al., 2009; Novakov et al., 2005). To study the content of $\mathrm{BC}$ in snow and ice, a routine which models snow layers based on meteorological data for among others snow fall and melt and the following BC deposition is included (Rypdal et al., 2009b). Fossil fuel and biofuel BC emissions are from Bond et al. (2004) and open biomass burning emissions for year 2004 are from the Global Fire Emissions Database (GFEDv2) (van der Werf et al., 2006). Total global fossil fuel plus biofuel emissions and open biomass burning emissions are $4.6 \mathrm{Tg} \mathrm{yr}^{-1}$ and $2.7 \mathrm{Tg} \mathrm{yr}^{-1}$ respectively.

\subsection{Black carbon in the OsloCTM2}

\subsubsection{Bulk parameterization}

In the bulk parameterization (henceforth abbreviated BULK) $\mathrm{BC}$ aerosols are characterized by total mass only, with no size resolution and only a simple representation of mixing state. At the time of emission $20 \%$ of the particles from fossil fuel and biofuel sources are assumed to be hydrophilic, while the remaining $80 \%$ are hydrophobic. Emissions from open biomass burning are $50 \%$ hydrophobic and $50 \%$ hydrophilic. Hydrophobic particles are then transferred to hydrophilic mode, where they are assumed to be for wet 
removal, at a constant rate given by an exponential decay of 1.15 days based on Cooke et al. (1999). Hence the model is run with only the $\mathrm{BC} / \mathrm{OC}$ aerosol application, and our regional simulations are performed by including emissions in one region at the time, setting all other $\mathrm{BC}$ emissions to zero.

Particles are removed by wet and dry deposition. Based on Cooke et al. (1999) the dry deposition velocity for hydrophilic aerosols is $0.025 \mathrm{~cm} \mathrm{~s}^{-1}$ over land and $0.2 \mathrm{~cm} \mathrm{~s}^{-1}$ over ocean, while a velocity of $0.025 \mathrm{~cm} \mathrm{~s}^{-1}$ is applied over all surfaces for hydrophobic particles. Hydrophilic aerosols are assumed to be $100 \%$ absorbed in the cloud droplets and are removed according to the fraction of the liquid plus ice water content of a cloud that is removed by precipitation (Berntsen et al., 2006). It is thus assumed $100 \%$ scavenging of hydrophilic particles by both water and ice clouds in large-scale precipitation and in convective precipitation.

\subsubsection{Microphysical parameterization}

Important aerosol characteristics such as settling velocity, optical and cloud nucleating properties and wet removal are dependent on particle size and mixing state, and studies have found the radiative forcing and climate impact to be stronger for internally than for externally mixed $\mathrm{BC}$ particles (Bauer et al., 2010; Bond et al., 2006; Chung and Seinfeld, 2002, 2005). A realistic representation of an aerosol population should therefore include not only total mass of different species, but also a size distribution and the mixing state. The microphysical aerosol module M7 represents these characteristics and is described in detail in Vignati et al. (2004). M7 includes the main aerosol species; sea salt, mineral dust, sulfate and organic carbon, in addition to BC. The particles are separated into seven classes or modes. A lognormal distribution function is used to represent the size distribution and each mode is represented by the total particle number and mass, from which the average particle radius is calculated. Particles are allowed to interact, leading to aging and growth, and the aerosols are moved between modes. BC aerosols are separated into soluble (mixed) and insoluble particles, and they can exist in four modes: Aitken insoluble, Aitken soluble, accumulation and coarse. In the simulations with $\mathrm{M} 7$ all emissions of $\mathrm{BC}$ are assumed to be $100 \%$ hydrophobic and in the Aitken mode. Aging then occurs due to condensation of sulfuric acid produced in the gas-phase reaction $\mathrm{OH}+\mathrm{SO}_{2}^{-} \rightarrow \mathrm{H}_{2} \mathrm{SO}_{4}$ or coagulation with sulfate particles. M7 is coupled to the sulfur/oxidant chemistry in the CTM2 (Berglen et al., 2004), i.e. the production of sulfate is explicitly calculated and is dependent on the $\mathrm{SO}_{2}$ emissions and oxidant levels and thus variable in time and space. The chemistry scheme in the Oslo CTM2 calculates gas and aqueous phase sulfate when M7 is applied. Only the gas-phase sulfate is input to the microphysical module. Nucleation and condensation then proceeds as described in Vignati et al. (2004).

The wet removal of BC and sulfate is not changed in M7. The parameterization of dry deposition in M7, however, dif- fers from that in BULK. While constant dry deposition velocities are used in BULK, the dry deposition of all aerosol species in M7 is calculated following the scheme by Seinfeld and Pandis (1998), where dry deposition velocities depend on particle size and density, turbulence close to surface and the resistance of the laminar sub layer (see also Grini (2007) for more details).

Since the fate of the BC particles now is dependent on the amount of available sulfate, the regional simulations must be set up differently than with BULK. Regional simulations with M7 are performed by reducing fossil fuel and biofuel emissions by $20 \%$ in each of the regions separately. Regional contributions are then calculated as the difference from the reference simulation and scaled to a $100 \%$ reduction. Due to non-linearities this might not be entirely equal to a $100 \%$ reduction.

\section{Results and discussion}

This section presents results from the simulations, first for atmospheric concentrations and then for BC in snow and ice. In both cases, we present first results for total, global emissions and then for regional simulations.

\subsection{Atmospheric BC}

\subsubsection{Global concentrations}

The annual mean surface concentration of total BC (fossil fuel, biofuel and biomass burning) is shown in Fig. 1. Maximum concentrations of a few $\mu \mathrm{g} \mathrm{m}^{-3}$ are found close to major source regions and the concentration decreases rapidly with distance, reflecting the short atmospheric lifetime of BC. Results are similar to those modelled by Koch et al. (2007). We find that over most continental regions the ratio M7/BULK is 2 or lower, while the ratio increases with distance from main emission source regions. With M7 there is a significant increase in concentrations at high latitudes, especially in the Northern Hemisphere. With transport, meteorology and wet removal processes unchanged in both aerosol parameterizations, this increase can be attributed mainly to the change in lifetime due to the different treatment of aging. M7 also involves changes to the dry deposition scheme for aerosols. However, wet removal is the dominating loss mechanism for BC (although dry deposition could play a more important role during high-latitude winter (Spackman et al., 2010)), so we expect the impact on surface concentration of these changes to be smaller than the impact of changes in lifetime. Annual mean zonally averaged burden reveals increased BC at all latitudes with M7, with the highest relative change, up to $90 \%$, at the highest latitudes. The global mean lifetime of BC (calculated as the ratio of burden to total emissions of $\mathrm{BC}$ ) is 5.8 days and 7.4 days with BULK and M7 respectively, while the global burden is 0.12 and $0.16 \mathrm{Tg}$. This increase in lifetime and burden is similar to results in Vignati 
Annual mean BC surface concentration $\left[\mathrm{ng} \mathrm{m}^{-3}\right.$ ] (BULK)

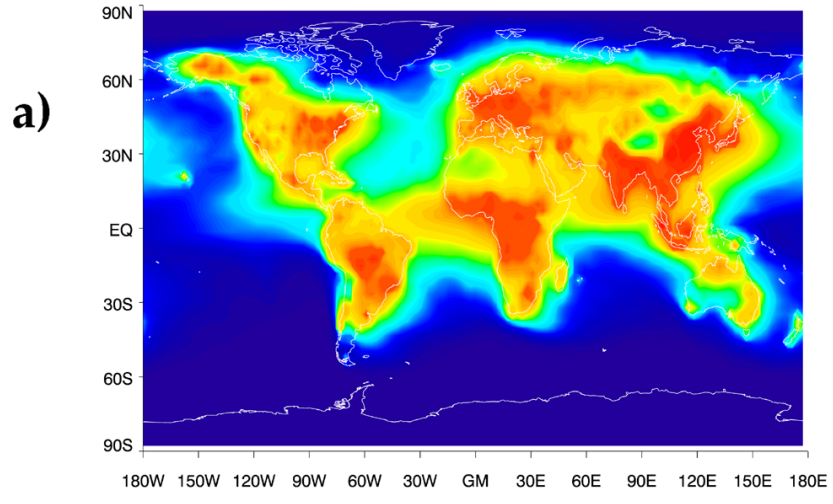

$\begin{array}{lllllllllll}0.0 & 2.4 & 4.8 & 7.2 & 9.7 & 22.0 & 36.0 & 50.0 & 64.0 & 250.0 & 1500.0\end{array}$ b)
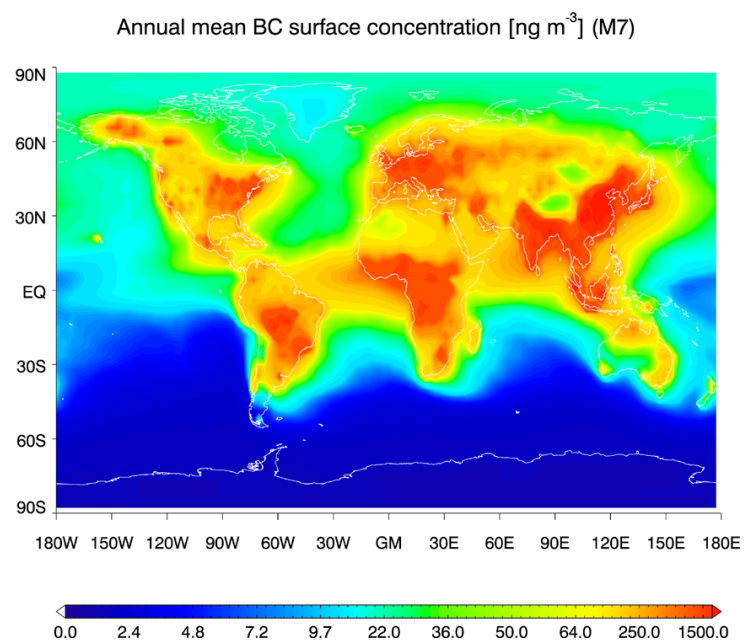

Fig. 1. Annual mean surface concentration of $\mathrm{BC}\left[\mathrm{ng} \mathrm{m}^{-3}\right]$ using (a) BULK and (b) M7.

et al. (2010), who found global burdens of 0.11 and $0.14 \mathrm{Tg}$ (corresponding to lifetimes of 4.7 and 6.2 days) using a bulk parameterization and the M7 respectively. Results are also similar to Liu et al. (2011) who found an increase in lifetime from 6.9 to 9.5 days when using an improved parameterization of $\mathrm{BC}$ accounting for regional and seasonal variations in aging instead of a bulk configuration. Previous studies report BC lifetimes ranging from 4 to 15 days (Schulz et al., 2006; Vignati et al., 2010). Examination of the surface concentration in different seasons reveals that the high-latitude increase is strongest in fall and winter. During these months the production of sulfate is lower due to lack of solar radiation and this reduces the coating of the $\mathrm{BC}$ particles, and thus results in a slower aging. Hence, M7 reveals significant seasonal and regional variations in $\mathrm{BC}$ aging time. Berglen et al. (2004) found that the OsloCTM2 tends to overestimate $\mathrm{SO}_{2}$ and underestimate sulfate during Northern Hemisphere winter. If sulfate concentrations were higher it would have implications for the M7, leading to a faster aging.

Figure $2 \mathrm{a}$ and $\mathrm{b}$ show vertical profiles of total $\mathrm{BC}$ concentrations averaged globally and north of $65^{\circ} \mathrm{N}$ in January and July with BULK and M7. Both parameterizations show a general decrease in globally averaged concentration up to approximately $7 \mathrm{~km}$. Above this the concentration is relatively constant with height, i.e. the mixing ratio increases with height indicating convection or long-range isentropic transport. There is an increase with M7 compared to BULK. North of $65^{\circ} \mathrm{N}$ this difference between parameterizations is largest below $10 \mathrm{~km}$ in January. During winter north of $65^{\circ} \mathrm{N}$ the maximum concentration with BULK is found above $10 \mathrm{~km}$ and the concentration with M7 varies little with altitude, consistent with high-altitude isentropic transport to this region (Stohl, 2006). As will be shown in Sect. 3.1.2, emissions in China, which have the potential to be lifted to higher altitudes due to convection and be transported northwards at this height, give the dominating contribution to high altitude $\mathrm{BC}$ north of $65^{\circ} \mathrm{N}$.

The climate effects of $\mathrm{BC}$ particles depend on their altitude in the atmosphere (Ban-Weiss et al., 2011; Hansen et al., 2005; Johnson et al., 2004; Koch and Del Genio, 2010; Samset and Myhre, 2011) and it is important to properly measure and model the vertical distribution. $\mathrm{BC}$ aerosols at high altitudes are more likely to be above clouds and thus have a stronger direct effect due to cloud reflection from below (Haywood et al., 1997; Satheesh, 2002). On the other hand, heating due to $\mathrm{BC}$ in one layer inhibits convection from the layer below and increases cloud cover in the lower layer (Hansen et al., 2005). Koch and Del Genio (2010) provide a review of the impact of absorbing aerosols on cloud cover (semi-direct effect). Absorbing aerosols can either decrease or increase cloud cover, depending among other on altitude of the aerosols relative to the cloud and the cloud type. BanWeiss et al. (2011) investigate the radiative forcing (direct and semi-direct effects) of BC at different altitudes using a general circulation model with prescribed aerosol concentrations, and find a strong dependence of the climate response on the altitude of the aerosols.

Figure $2 \mathrm{c}$ to $\mathrm{f}$ show modelled vertical profiles of total BC from the OsloCTM2 with BULK and M7 compared to measurements from flights during the HIAPER Pole-to-Pole Observation campaign (HIPPO1) (Schwarz et al., 2010b). For each latitude band, model averages are over all data in the longitude range spanned by the flight track. The measurement campaign was carried out in the period 923 January 2009 over the Pacific Ocean; modelled values are monthly averages for January 2006. There are important differences between measurements and model results in terms of e.g. meteorological conditions, emissions (such as episodic biomass burning not captured by the model), averaging area and temporal resolution. These should be kept in mind as they make direct comparison difficult. The 

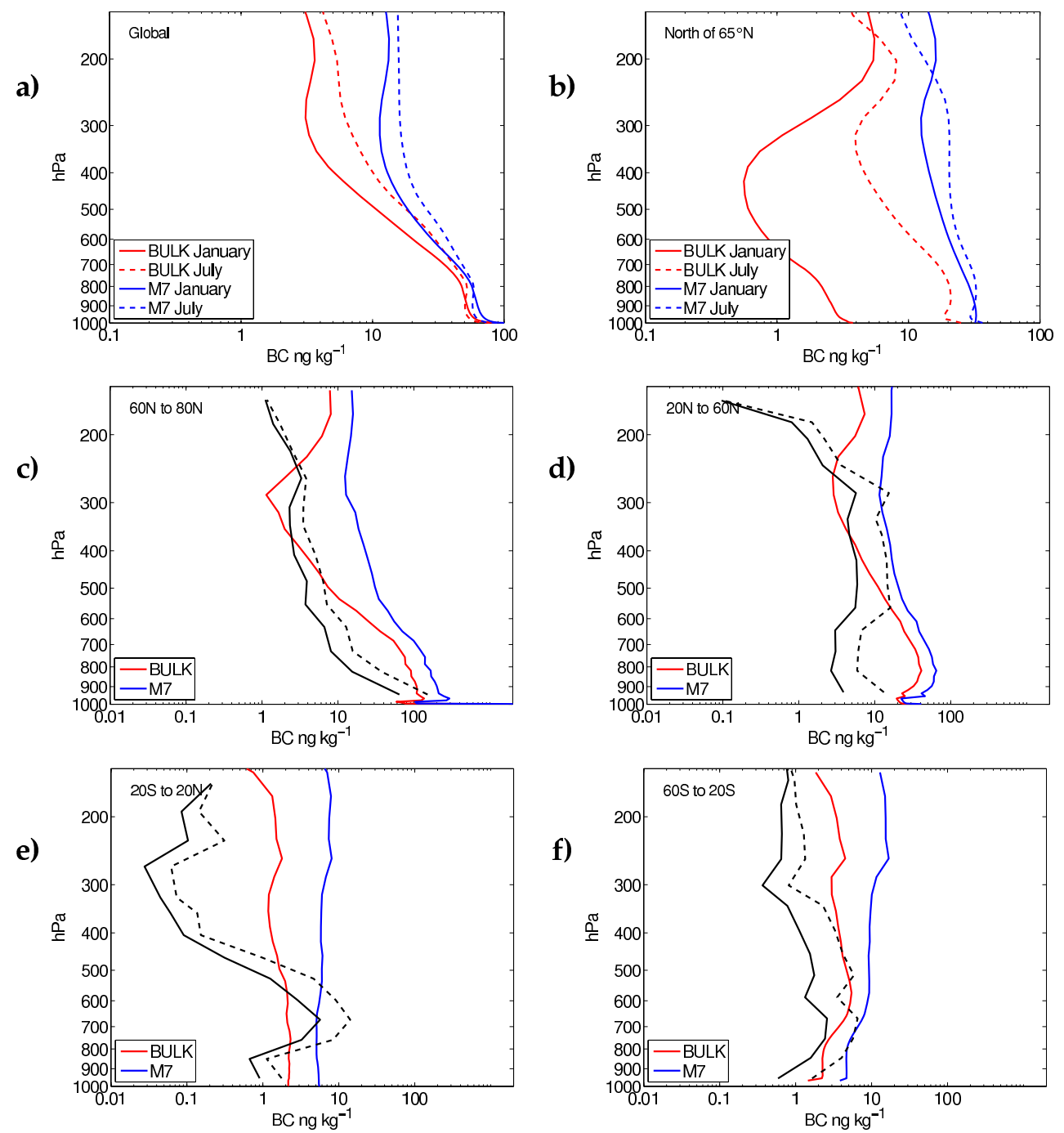

Fig. 2. Vertical distribution of BC $\left[\mathrm{ng} \mathrm{kg}^{-1}\right]$ averaged (a) globally and (b) north of $65^{\circ} \mathrm{N}$ with BULK (red) and M7 (blue) in January (solid) and July (dashed). (c) to (f) shows modelled vertical distribution in January compared to measurements (solid black line, dashed line gives +1 SD) over the Pacific Ocean from Schwarz et al. (2010).

model generally overestimates concentrations compared to measurements, especially at higher altitudes in tropical and northern mid-latitudes. For some regions measurements also show a stronger vertical gradient than model results. Furthermore, M7 leads to an increase in concentrations relative to BULK, and hence does not lead to any improvements compared to the measurements. These findings are in line with results from Koch et al. (2009) and Schwarz et al. (2010b) who compare observed vertical profiles to an ensemble of models, including the OsloCTM2 with the bulk parameterization, and find a tendency of the models to overestimate the $\mathrm{BC}$ load. Results are also similar to a comparison of OsloCTM2 results with measurements by Skeie et al. (2011). Skeie et al. (2011) perform multi-year simulations using emission estimates from Bond et al. (2007), with updated emissions for the Asian region (REAS) which capture the rapid economic growth since year 2000. A modified bulk parameterization is used, where the exponential decay is defined for separate latitude bands and seasons based on the M7 simulations in this study. This modified parameterization reduces the required computer resources, while still capturing most of the seasonal and regional variation in aging apparent when the full M7 module is applied.

Schwarz et al. (2010b) investigate the size distribution of the $\mathrm{BC}$ particles, finding more of the larger particles in Arctic pollution than in remote atmosphere or in fresh pollution. The SP2 detection range for refractory carbon is $\sim 100$ $600 \mathrm{~nm}$ volume-equivalent diameter (VED) (Schwarz et al., 2008); Schwarz et al. (2010a) found a conservative lower limit for detection of $90 \mathrm{~nm}$ VED. The SP2 is thus suitable for measurements of accumulation mode particles (Schwarz et al., 2008). Using the M7 allows us to investigate possible 

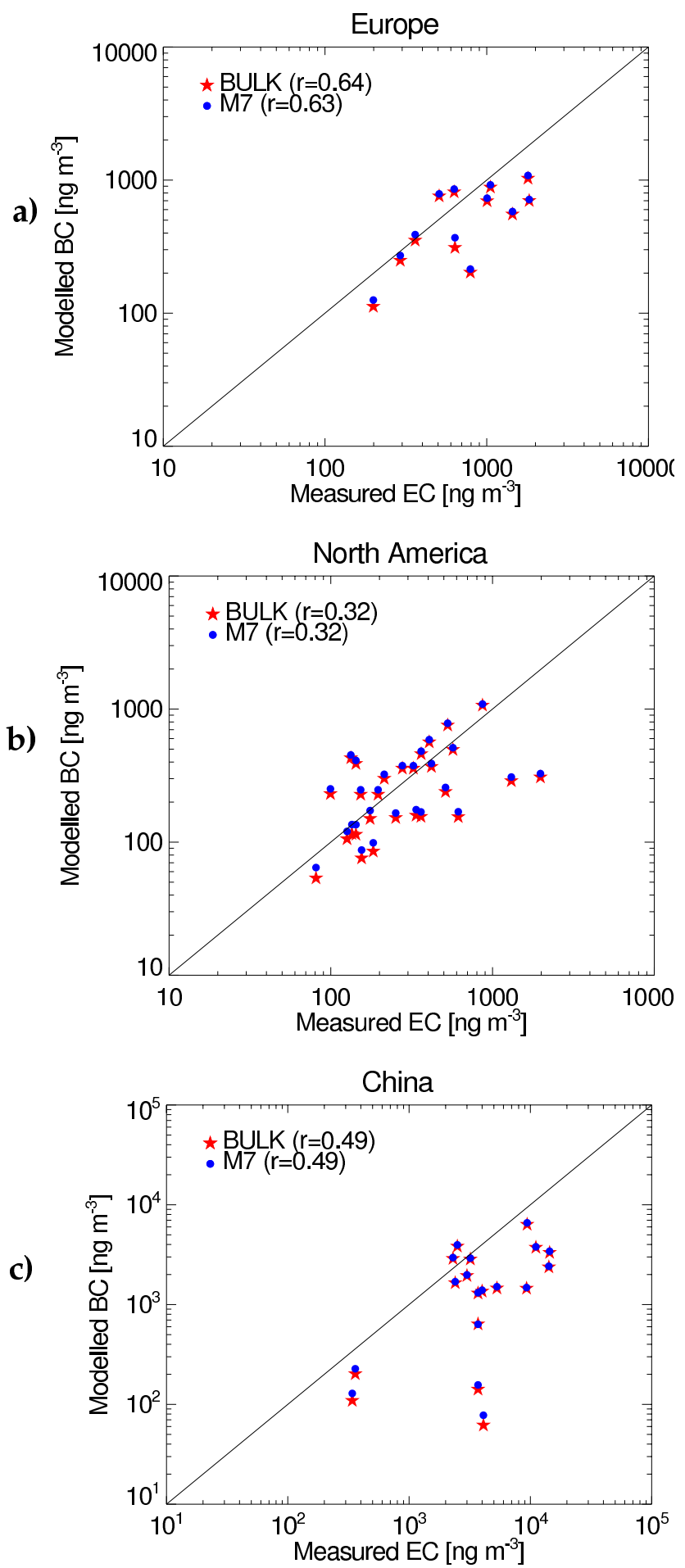

Fig. 3. Annual mean modelled (2005/2006) surface concentrations of BC $\left[\mathrm{ng} \mathrm{m}^{-3}\right]$ with BULK and M7 versus measurements in Europe (EMEP 2002/2003 campaign), North America (IMPROVE) and China (Zhang et al. (2008)). regional differences in how much of the $\mathrm{BC}$ that exist in the different modes by looking at the vertical profiles of each mode separately (not shown here). In the region 60 to $80^{\circ} \mathrm{N}$, we find that in January most of the $\mathrm{BC}$ particles are in the insoluble Aitken mode (0.005-0.05 $\mu \mathrm{m}$ dry radius interval). In this region, the transfer to soluble modes and subsequent growth is slow during winter with less sunlight and hence less production of sulfate. These particles are smaller than the detection range of the SP2. In the latitude bands between 20 to $60^{\circ} \mathrm{N}$ and $20^{\circ} \mathrm{S}$ to $20^{\circ} \mathrm{N}$ most particles in the lowest kilometers are in the accumulation mode both in January and July. The concentration of these particles decrease with height and at higher altitudes the insoluble Aitken mode still dominates. The high-altitude overestimation compared to measurements may be caused by too inefficient wet removal: There is no removal of particles in the insoluble mode in the model. However, it is possible that also insoluble particles can be scavenged in regions of convective precipitation. This will be tested in future simulations.

Vertical profiles of $\mathrm{BC}$ from flight campaigns in August and February over Central America and in April in Alaska are presented in Spackman et al. (2011) and Spackman et al. (2010). Averaged over the approximate region of the flight campaign in the Central American region $\left(75\right.$ to $85^{\circ} \mathrm{W}$ and 1 to $12^{\circ} \mathrm{N}$ ) the vertical gradient in the modelled profiles is less steep than in the measurements, resulting again in too high concentrations at higher altitudes with both parameterizations. The measured $\mathrm{BC}$ mass loadings in Alaska show an increase with altitude to $5 \mathrm{~km}$, reaching $150-250 \mathrm{ng} \mathrm{kg}^{-1}$. The air mass sampled during several of the flights was strongly influenced of biomass burning emissions; episodic biomass burning plumes are not captured by the CTM2. Modelled $\mathrm{BC}$ in the approximate region of the Alaskan flight (125 to $170^{\circ} \mathrm{W}$ and 63 to $77^{\circ} \mathrm{N}$ ) shows an increase with height using BULK, but values are lower than $1 \mathrm{ng} \mathrm{kg}^{-1}$ below $5 \mathrm{~km}$. With M7 values are relatively constant at around $16 \mathrm{ng} \mathrm{kg}^{-1}$ up to $5 \mathrm{~km}$.

Liu et al. (2011) compare vertical BC profiles with their original and improved aerosol parameterizations to measurements from the Arctic Research of the Composition of the Troposphere from Aircraft and Satellites (ARCTAS) flight campaign. They find significant increases in BC load with the improved parameterization compared to their original bulk configuration and improved vertical profiles compared to measurements. Averaged over the same regions we also find strong increases in $\mathrm{BC}$ concentrations with $\mathrm{M} 7 \mathrm{com}-$ pared to BULK and vertical profiles with M7 are in reasonable agreement with the improved vertical profiles in Liu et al. (2011).

Modelled annual mean (2005/06) surface concentrations of total $\mathrm{BC}$ are compared with measurements in Europe and the US from the EMEP 2002/2003 campaign (Yttri et al., 2007) and the IMPROVE database (http://vista.cira. colostate.edu/IMPROVE/, year 2005, 28 stations selected). For China we compare with measurements from Zhang et 

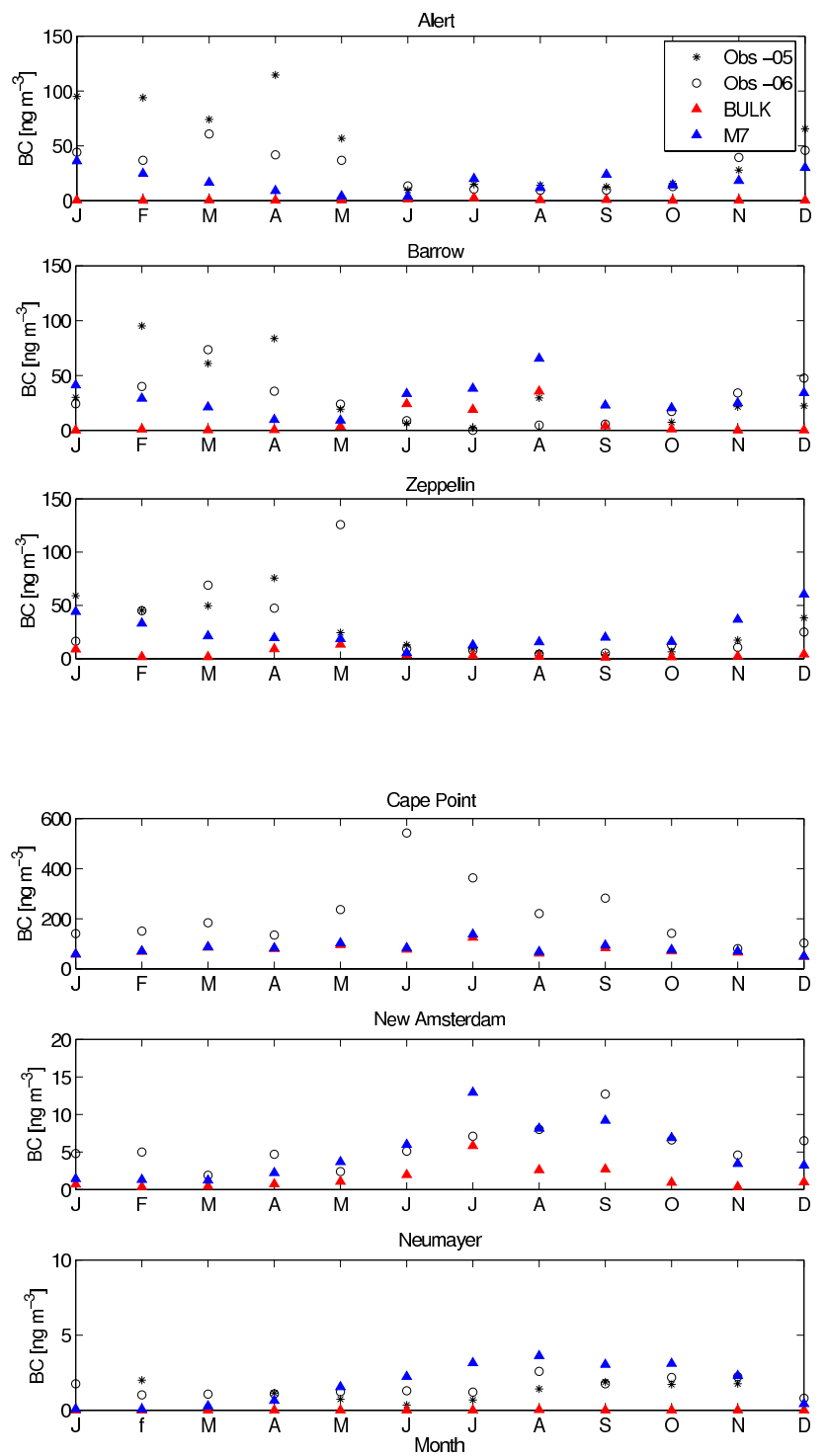

Fig. 4. Monthly mean modelled (year 2005/2006) BC surface concentrations $\left[\mathrm{ng} \mathrm{m}^{-3}\right.$ ] with BULK and M7 and measured (year 2005 and/or 2006) BC concentration at Alert, Barrow, Zeppelin, Cape Point, Amsterdam Island and Neumayer (Antarctica). Note that measurements are equivalent black carbon concentrations.

al. (2008). Model results are also compared to various measurements summarized in Jacobson (2002). Figure 3 shows scatterplots of surface air measurements versus model results for Europe, US and China. At the majority of stations in Europe and China the model underestimates concentrations compared to measurements. Averaged over all stations measured concentrations are approximately $35 \%, 20 \%$ and $84 \%$ higher than modelled concentrations in Europe, North America and China respectively. The large discrepancy between modelled and measured concentrations in China is not unexpected; China has experienced rapid economic growth since year 2000 and more recent inventories show significantly higher emissions than used in this study (Ohara et al., 2007; Skeie et al., 2011). Measurements summarized in Jacobson (2002) are separated into marine, rural and urban. The agreement between modelled and measured concentration is on average best for rural locations (not shown here). Concentrations are generally slightly higher with M7 than BULK, but few of the stations are located at a distance from the emission sources where the increase in concentration between the parameterizations is most significant (i.e. high northern or southern latitudes). Modelled values are all from the lowest model layer. The coarse grid in the OsloCTM2, as well as the different timing of measurements and model emission inventory, complicates the comparison due to the high temporal and spatial variability of $\mathrm{BC}$ concentrations.

The bulk version of the OsloCTM2 was part of the multimodel evaluation study by Koch et al. (2009) with similar results as in this study. However, in Koch et al. (2009) the OsloCTM2 was found to overestimate surface concentrations of $\mathrm{BC}$ compared to measurements in Europe, the opposite of results here. The CTM2 simulations in Koch et al. (2009) used fossil and biofuel BC emissions from Cooke et al. (1999). These estimates are higher than the Bond et al. (2004) estimates which are currently used.

Surface concentration and vertical load of $\mathrm{BC}$ revealed a strong increase in concentrations north of $65^{\circ} \mathrm{N}$ during winter with M7 compared to BULK and comparison with measured vertical profiles suggests that this is an improvement. Here we investigate this further by comparing modelled and measured surface concentrations at three Arctic locations. Shindell et al. (2008) showed that models generally produce lower surface concentrations of $\mathrm{BC}$ than measured at high-latitude stations, especially during winter. This is also the case for the OsloCTM2. Figure 4 shows monthly mean measured and modelled surface concentrations at Alert, Barrow and Zeppelin. Measurements from Barrow and Zeppelin are from the NOAA/ESRL/GMD and EBAS databases. Measurements from Alert were provided by Sangeeta Sharma at Environment Canada. The concentrations with BULK are generally very low compared to measurements. Using M7 leads to higher concentrations and improvements in the seasonal cycle; particularly the wintertime accumulation of $\mathrm{BC}$ (i.e. the Arctic Haze) is improved compared to results with BULK. The model still underestimates the magnitude of concentrations during winter and spring. Similarly, Koch (2001) and Liu et al. (2011) also find a significant improvement in both magnitude and seasonal cycle of modelled BC in the Arctic when assuming that the solubility of $\mathrm{BC}$ depends on exposure to sulfate compared to using a fixed aging rate. The oxidation of $\mathrm{SO}_{2}$ depends mainly on availability of oxidants, which is lowest during winter. This leads to the largest differences between BULK and M7 during winter. During spring, measured concentrations are likely to be influenced by emissions from biomass burning, which might not be properly captured by the model emission inventory. For instance, agricultural burning in Eastern Europe caused record high air 
pollution episodes in the European Arctic in spring 2006 (Stohl et al., 2007) as can be seen from the Zeppelin measurements in Fig. 4.

At Barrow the model shows high concentrations in summer, associated with plumes of biomass burning emissions. These high values are not seen in the 2005 surface measurements (measurements for summer 2006 has several missing values). However, measurements of aerosol light absorption and scattering from the NOAA/ESRL/GMD database show occasional peaks also during summer. The low surface values thus show little downward transport, indicative of a stable boundary layer. The vertical mixing in the model might be too efficient or the height of biomass burning emissions too low, resulting in too high concentrations of aerosols at the surface. In addition to modelling uncertainties, uncertainties are also related to emission inventories (Bond et al., 2004; van der Werf et al., 2006) and measurements (Bond et al., 1999; Massoli et al., 2009; Schwarz et al., 2010b). Bond et al. (2004) estimate a factor 2 uncertainty in the global BC emission inventory. Uncertainties in open biomass burning emissions can also be large and are mainly related to uncertainty in burned area, fuel load and combustion completeness (van der Werf et al., 2006). Furthermore, there is significant inter-annual variability in agricultural and forest fires.

We also compare modelled surface concentrations to measurements at Southern Hemisphere stations; Cape Point (personal communication Casper Labuschagne, South African Weather Service, March 2012), Amsterdam Island (Sciare et al., 2009), and Neumayer Antarctica (personal communication Rolf Weller, Alfred Wegener Institute for Polar and Marine Research, March 2012). At Cape Point, only year 2006 measurements are available, while values for Amsterdam Island are averaged over the measurement period 2004-2007. The M7 appears to be doing a reasonable job at these locations. At Cape Point there is little difference between the two parameterizations and they both agree well with measurement, except during Southern Hemisphere winter when values are underestimated. At Amsterdam Island there is significant improvement with M7 compared to BULK, especially during winter. During summer both parameterizations underestimate the concentrations. Finally, at Neumayer the concentrations using BULK are very low, while using M7 leads to a similar change as in the Arctic and at Amsterdam Island with strong increases in concentrations, particularly during winter. This improves the comparison, but also leads to an overestimation of concentrations during winter. Neumayer is very remote and measured concentrations are low and show significant interannual variability. The better agreement at these latter two remote locations, where concentrations are only affected by long-range transport, supports the suggestion that model concentrations are underestimated partly due to missing emissions in the Northern Hemisphere (see also Sect. 3.2.1).

\subsubsection{Regional contributions to Arctic BC}

Figure $5 \mathrm{a}$ and $\mathrm{b}$ show monthly mean absolute contribution of fossil fuel and biofuel BC from the four emission source regions to total $\mathrm{BC}$ burden north of $65^{\circ} \mathrm{N}$. Using BULK (Fig. 5a), emissions in Europe give the highest contributions to the $\mathrm{BC}$ burden. Contributions from China, Russia and North America are of similar magnitude. Annually averaged, fossil fuel and biofuel BC from Europe and North America contributes 22 and $5 \%$ respectively to total BC burden north of $65^{\circ} \mathrm{N}$. Russia and China give equal contributions of $8 \%$. The remaining fraction consists both of fossil fuel and biofuel BC emissions from regions not considered here and biomass burning emissions. Investigation of the vertical distribution of BC, shown in Fig. $5 \mathrm{c}$ and d, reveals that European and Russian emissions are most important near the surface and in the lower troposphere, while at higher altitudes $\mathrm{BC}$ from China dominates. This is consistent with previous studies (Shindell et al., 2008; Stohl, 2006). When M7 is used, the absolute contributions to total $\mathrm{BC}$ burden north of $65^{\circ} \mathrm{N}$ display a much clearer seasonal pattern for all regions, with maxima during late fall and winter and low contributions during summer (Fig. 5b). This seasonal variation is especially evident for emissions in Europe and Russia, which are located at high latitudes, and less pronounced for emissions in China. The contributions from Europe and Russia increase strongly below $5 \mathrm{~km}$ in January compared to BULK, as seen in Fig. 5d. Annual average percentage contributions to total $\mathrm{BC}$ burden change only by a few percentage points, to $18 \%$ for Europe and $7 \%$ for North America. There is no change in the contribution from China. The contribution from Russia increases to $13 \%$ with $\mathrm{M} 7$.

Here we have focused on BC from fossil fuel and biofuel sources. There are also contributions from open biomass burning emissions, of which significant fractions can be of anthropogenic origin. Because the amount of co-emitted $\mathrm{SO}_{2}$ is lower from biomass burning than from fossil fuel sources, the changes between BULK and M7 are likely smaller than for fossil fuel BC. The biomass burning emissions also occur mainly during spring and summer, while differences between the parameterizations are most pronounced during fall and winter. Skeie et al. (2011) explore also the contributions from biomass burning BC using the BULK scheme of the CTM2 and find that biomass burning in Russia contributes most to higher-altitude concentrations during spring, while biomass burning in North America is important during summer. The contribution from Europe is found to be mainly of fossil fuel and biofuel origin.

Calculations reveal that the aging time (calculated for each regional simulation as burden of insoluble Aitken mode particles to total emissions of $\mathrm{BC}$ in that region) for fossil fuel and biofuel BC emissions in Russia vary from approximately 3 days in July to almost 8 days in January. For emissions in Europe there is a similar seasonal variation. For emissions in China the aging time remains approximately one day 

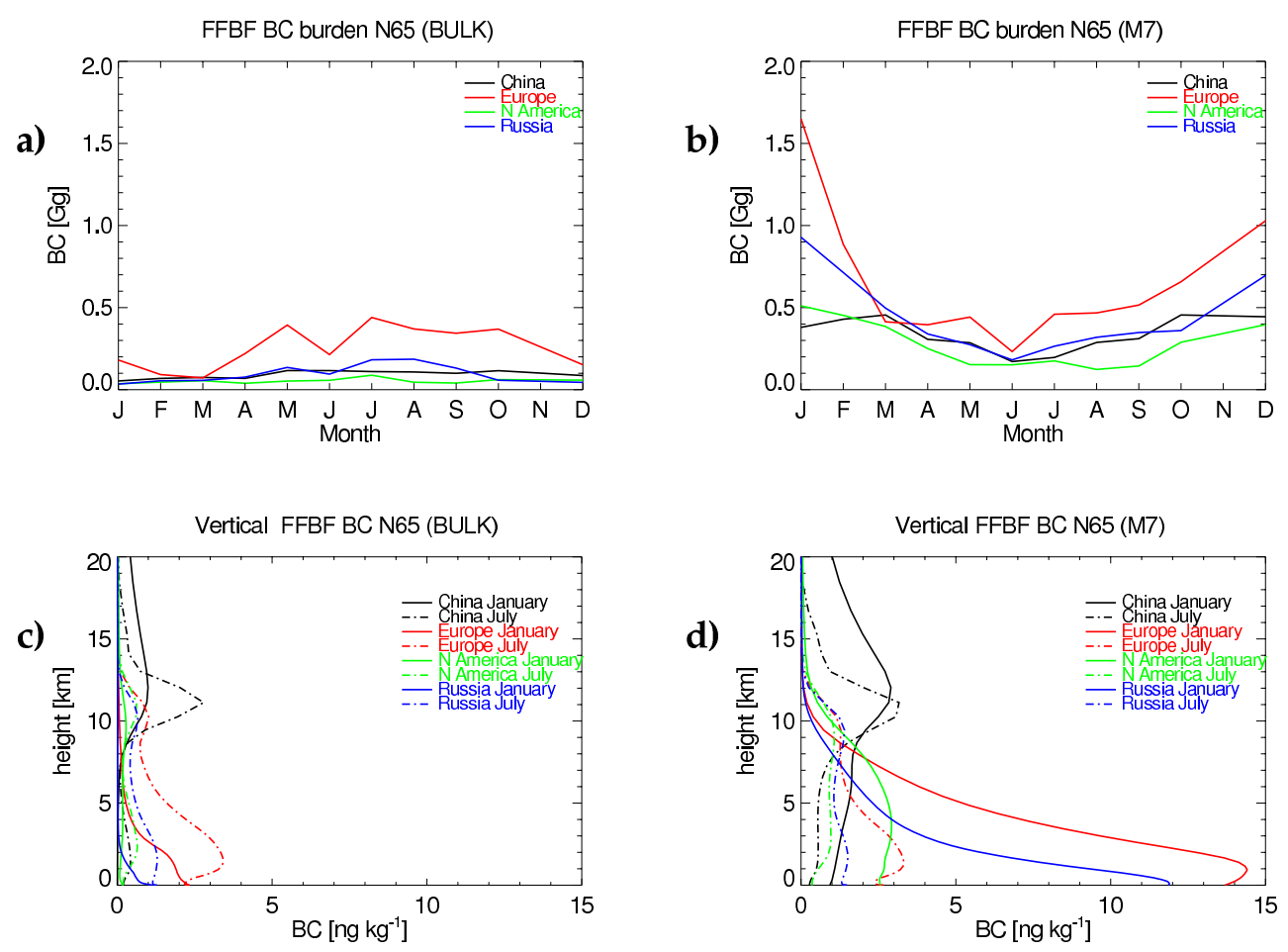

Fig. 5. Regional contribution from Europe, Russia, China and North America to monthly mean fossil and biofuel (FFBF) BC burden [Gg] in the atmosphere north $65^{\circ} \mathrm{N}$ with (a) BULK and (b) M7, and to vertical distribution [ng kg-1 $]$ of fossil and biofuel BC in January (solid) and July (dashed) with (c) BULK and (d) M7.

throughout the year, which is reasonable considering the high emissions of $\mathrm{SO}_{2}$ and less seasonal variation in solar radiation.

Studies using single-particle soot photometer (SP2) measurements in urban plumes (e.g. Moteki et al., 2007; Shiraiwa et al., 2007) suggest that the short aging time for emissions in China calculated in this study is reasonable. However, to our knowledge such measurements have not been conducted at higher latitudes. Furthermore, Riemer et al. (2010) calculate $\mathrm{BC}$ aging time-scales in an idealised urban plume (with temperature, mixing height and relative humidity representative of the Los Angeles Basin at $34^{\circ} \mathrm{N}$ (Riemer et al., 2009)) between $\sim 0.01$ and 11 hours during the day and 6 and 54 hours during night. These studies indicate that also water-soluble organic carbon and nitrate can be important for the coating of $\mathrm{BC}$ particles. Neither of these species contributes to the coating of $\mathrm{BC}$ by condensation in the standard M7 module used here. Observations and modelling indicate that the concentration of nitrate is larger during winter than during summer due to the increase in saturation pressure of $\mathrm{HNO}_{3}$ with temperature and less competition with $\mathrm{SO}_{2}$ for available ammonia (Jaffe et al., 2005; Myhre et al., 2006). Myhre et al. (2006) also found low nitrate concentration outside industrialized regions. Inclusion of nitrate in the coating of BC by condensation could thus lead to a more rapid aging closer to emission source regions and hence less potential for long- range transport. However, because wet removal is lower during winter at high latitudes, accounting for aging of $\mathrm{BC}$ by nitrate from these emissions sources could result in more $\mathrm{BC}$ in reaching the Arctic in the soluble mode. These particles would then be available for wet removal in the model. Furthermore, nitrate aerosols are expected to become more important in the future (Bauer et al., 2007; Bellouin et al., 2011), which could increase the importance of this aging mechanism. The production of oxidation products of VOCs with low volatility that can form secondary organic aerosols (SOA) occurs predominately from natural sources and is thus most important during the summer season. Some compounds included in anthropogenic emissions can form SOA through oxidation in the atmosphere, but the contribution to global SOA budgets from these species has been found to be small compared to the contribution from naturally emitted species (Hoyle et al. (2007) and references therein). Accounting for condensation of organics in the coating off $\mathrm{BC}$ would mainly impact the aging timescales during summer.

\section{2 $B C$ in snow and ice}

\subsubsection{Global results}

Figure 6 shows concentration of total $\mathrm{BC}$ in snow and ice in April (monthly mean in the top $5 \mathrm{~cm}$ of snow) in the Northern Hemisphere with BULK and the absolute difference between 
$\mathrm{BC}$ in snow/ice [ng g ${ }^{-1}$ ], April (BULK)

a)

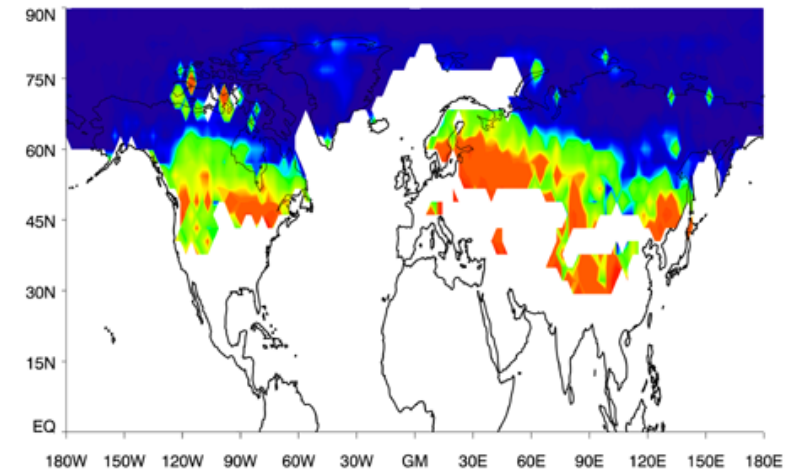

$\begin{array}{llllllllllll}0.0 & 1.4 & 2.9 & 4.3 & 5.7 & 7.2 & 8.6 & 26.0 & 54.0 & 82.0 & 108.0 & 1000.0\end{array}$ b)

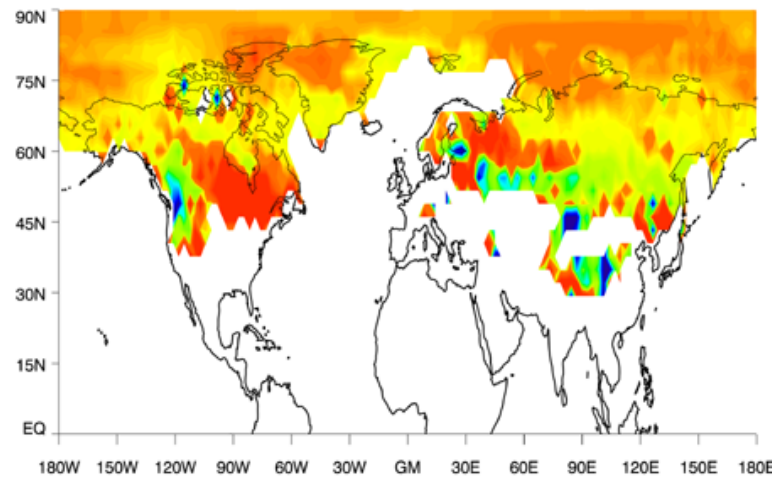

Fig. 6. $B C$ concentration $\left[\mathrm{ng} \mathrm{g}^{-1}\right]$ in snow and ice in April in the Northern Hemisphere (in the top $5 \mathrm{~cm}$ of snow) (a) using BULK and (b) difference between $\mathrm{M} 7$ and BULK.

Table 1. Ratio of modelled and measured $\mathrm{BC}$ in snow averaged of all measurements in individual regions as given by Doherty et al. (2010).

\begin{tabular}{lcc}
\hline & \multicolumn{2}{c}{$\begin{array}{c}\text { Ratio modelled/ } \\
\text { measured BC } \\
\text { concentration in snow }\end{array}$} \\
\hline Region & BULK & M7 \\
Arctic Ocean & 0.79 & 1.20 \\
Canadian Arctic & 0.86 & 1.07 \\
Alaska N. slope & 1.43 & 0.81 \\
Canada sub-Arctic & 0.15 & 0.15 \\
Greenland & 0.79 & 0.83 \\
Svalbard & 0.08 & 0.19 \\
Troms $\varnothing$ & 1.79 & 1.96 \\
Russia & 0.01 & 0.02 \\
\hline
\end{tabular}

M7 and BULK. The highest concentrations are found close to source regions in Asia and Europe. Concentrations on the order of 20-40 $\mathrm{ng} \mathrm{g}^{-1}$ are found over parts of Central Asia, Siberia and North America. North of $65^{\circ} \mathrm{N}$ concentrations are mostly small, but with some occasional areas with high values. At high latitudes there is an increase in the $\mathrm{BC}$ concentration in snow and ice in the simulation with M7. Close to some source regions the general increase in BC lifetime in M7 leads to reduced concentration in snow since particles can now be transported over larger distances.

Modelled BC concentrations in snow are compared to measurements from Doherty et al. (2010) made in the Arctic between 2005 and 2009. Ratios of modelled and measured concentrations averaged over each region are given in Table 1 . The agreement is quite good for Greenland, Canadian Arctic and the Arctic Ocean. For Troms $\varnothing$ the model overestimates concentrations with both parameterizations, while for the Alaska North slope using M7 instead of BULK im- proves the comparison. For Svalbard, sub-Arctic Canada and especially Russia the model results are much lower than measurements. M7 generally leads to higher averaged concentrations than BULK. However, in the latter regions this only improves the comparison to measurements somewhat. The underestimation might be caused by too inefficient scavenging by snow in the model; in the OsloCTM2 only soluble particles are removed by precipitation, while a large fraction of the particles north of $65^{\circ} \mathrm{N}$ are found to be in the insoluble Aitken mode. Studies have shown that insoluble particles can act as ice nuclei through immersion and contact freezing (Hoose et al., 2010) and thus be scavenged. However, increased wet scavenging would lead to lower atmospheric concentrations, while results in previous sections showed that M7 in fact leads to improved representation of atmospheric BC concentrations in the Arctic. Thus, in addition to wet scavenging, the underestimation is also likely a result of too inefficient transport of $\mathrm{BC}$ to high latitudes in the model and/or too low emissions. Hegg et al. (2009) and Hegg et al. (2010) found indications of contributions from biomass sources to the $\mathrm{BC}$ in Arctic snow, which are not apparent in the model results. Missing or underestimated emission sources such as domestic wood burning and waste burning at high latitudes could therefore partly explain the underestimation.

\subsubsection{Regional contributions}

Finally, we investigate the regional contribution of fossil fuel and biofuel $\mathrm{BC}$ to total $\mathrm{BC}$ concentration in snow and ice north of $65^{\circ} \mathrm{N}$ as shown in Fig. 7. The figure shows monthly mean absolute contributions through one snow season, from September to June. The absolute contribution is largest for European emissions throughout the year, followed by North America and Russia. The most significant change with M7 compared to BULK is a strong increase in the contribution 

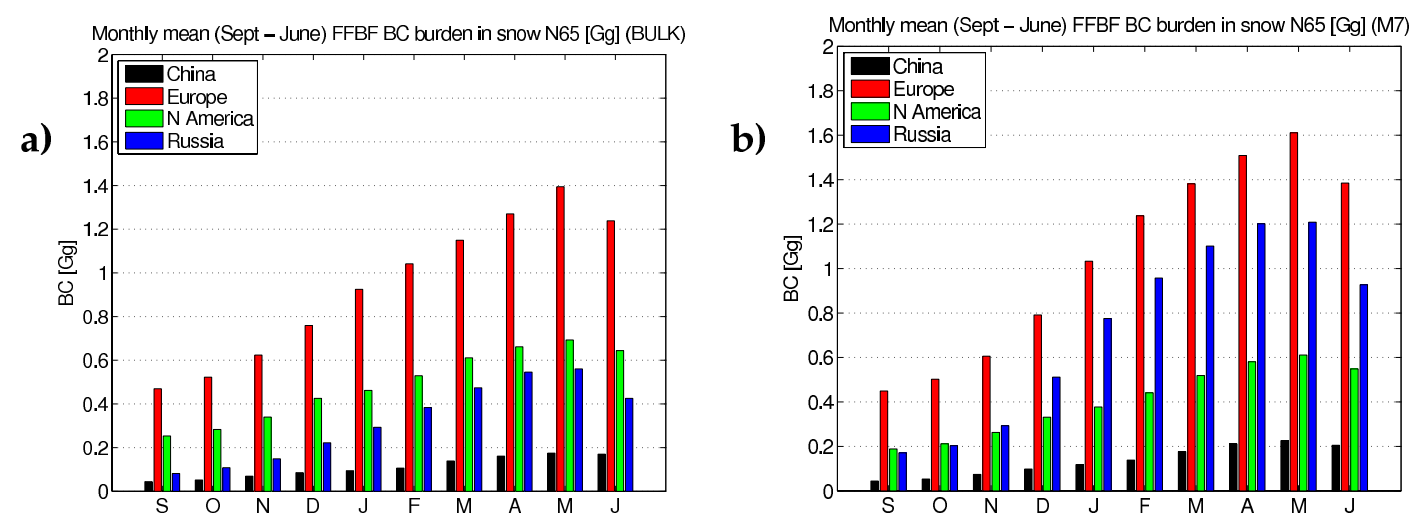

Fig. 7. Regional contribution from Europe, Russia, China and North America to monthly mean (September to June) fossil and biofuel (FFBF) BC burden $[\mathrm{Gg}]$ in snow and ice north of $65^{\circ} \mathrm{N}$ using (a) BULK and (b) M7.

from emissions in Russia, which now becomes more important than North America. As for contributions to atmospheric BC burden in Sect. 3.1.2, fossil fuel and biofuel BC from Europe gives the highest percentage contribution to total $\mathrm{BC}$ in snow and ice north of $65^{\circ} \mathrm{N}$ in both parameterizations, approximately $30 \%$ on annual average. For the remaining regions the percentage contributions and ranking differ somewhat from the contributions to atmospheric BC burden. With both BULK and M7 emissions in China contribute only $3 \%$ to $\mathrm{BC}$ in snow and ice, compared to $8 \%$ to the atmospheric burden. The contribution from China to BC in snow and ice is thus less than both Russia and North America, which contribute 10 and $16 \%$ respectively with BULK. Again, the contribution from Russia is most affected when M7 is used instead and increases to $19 \%$, making Russia the second largest contributor now. With M7 the contribution from North America decreases to $11 \%$, while there is little change in contributions from Europe. The relative importance of emissions in different regions in terms of $\mathrm{BC}$ in the Arctic thus depends both on the chosen parameterization and on whether we look at atmospheric BC or at the burden in snow/ice. However, the dominating contribution from emissions in Europe is consistent in our study.

\section{Conclusions}

Two parameterizations of black carbon (BC) aging in the chemistry transport model OsloCTM2 are compared and the effect of including aerosol microphysics on distribution, lifetime and transport of BC is investigated. In addition we focus on the impact on regional contributions from selected emission source regions to $\mathrm{BC}$ in the Arctic atmosphere and snow/ice. Using a bulk parameterization (BULK) with constant transfer from hydrophobic to hydrophilic mode, despite giving reasonable results globally, does not capture possible geographical and temporal variations in aging time. Using a microphysical module (M7), which includes a representa- tion of mixing state and size distribution and allows for aging through particle interaction, reveals a significant regional and seasonal variation in aging. This is especially apparent at high latitudes where lack of solar radiation during winter leads to a slower production of sulfate and thus to a slower aging and longer lifetime of BC.

In general, atmospheric surface concentrations increase with M7 compared to BULK, especially at high latitudes during winter. Inclusion of the seasonally and regionally varying $\mathrm{BC}$ aging improves the model performance at Arctic stations like Barrow, Alert and Zeppelin compared to observations. In particular the representation of $\mathrm{BC}$ accumulation during winter, where it contributes to the Arctic Haze phenomenon, is improved. These results agree well with other studies (Liu et al., 2011; Vignati et al., 2010). Since the climate impact of $\mathrm{BC}$ aerosols depends on their vertical location, it is important to both measure and model the vertical distribution of BC properly (Ban-Weiss et al., 2011; Koch and Del Genio, 2010). Comparison with vertical profiles shows that the model generally overestimates the BC concentration, especially at higher altitudes. Using M7 increases concentrations compared to BULK and hence exacerbates the overestimation. One exception is measurements at high northern latitudes.

The concentration of $\mathrm{BC}$ in snow and ice increases slightly with M7, with some exceptions close to source regions. Model results and measurements agree quite well in some Arctic regions, while both parameterizations significantly underestimates BC in snow and ice compared to measurements sampled in Russia, sub-Arctic Canada and Svalbard. Discrepancies can arise from uncertainties in measurements and the emission inventory and from the coarse resolution of the model. Additionally, the treatment of removal of particles by snow in the model and transport of $\mathrm{BC}$ to high latitudes can be part of the explanation. A large fraction of the modelled atmospheric increase in $\mathrm{BC}$ concentration consists of particles in the insoluble mode. These are currently not 
removed by precipitation, but studies indicate that insoluble particles can act as freezing nuclei and be scavenged by snow.

Recent studies using single-particle soot photometer (SP2) measurements show that water soluble organic carbon and nitrate can contribute to coating of BC particles through condensation (Moteki et al., 2007; Oshima et al., 2009; Shiraiwa et al., 2007). The M7 currently only includes coating by sulfate and accounting for other species might affect the aging and should be considered in future work. Using the M7 significantly increases the computer time. One possible compromise is to use constant exponential transfer within given latitude bands based on simulations with M7. This is useful for studies where many and/or long model runs are required, such as for comparisons of sources, sectors and regions (e.g. AMAP, 2011) or for calculating time series (e.g. Skeie et al., 2011). More sophisticated schemes like M7 does not necessarily improve the model performance, but allow for more realistic variability and understanding of physical processes.

The regional contributions to $\mathrm{BC}$ in the Arctic are affected by the inclusion of seasonally and regionally varying $\mathrm{BC}$ aging and the ranking of the regions also differ depending on whether we focus on atmospheric $\mathrm{BC}$ or the burden in snow/ice. However, a consistent feature here is that fossil fuel and biofuel emissions in Europe contribute most to the total BC load north of $65^{\circ} \mathrm{N}$, with annual average contributions of approximately $20 \%$ to total atmospheric $\mathrm{BC}$ and $30 \%$ to total BC in snow/ice. North America gives the smallest annual average contribution to atmospheric $\mathrm{BC}$, while China contributes least to $\mathrm{BC}$ in snow/ice. Contributions to $\mathrm{BC}$ in snow/ice from emissions in Russia increase from $10 \%$ with BULK to $19 \%$ with M7, making it more important than North America which was the second most important region with BULK. European and Russian emissions are most important in the lower troposphere, while emissions from China dominate at higher altitudes. With M7, the absolute contributions from all regions display a much clearer seasonal pattern with maxima during late fall and winter and low contributions during summer, and particularly for Russia there is a significant increase during winter compared to BULK. One implication is that the timing of emission reductions in individual regions and sectors can affect the resulting reduction in Arctic BC. These changes show that it is important to consider the representation of aerosol microphysics to identify the most efficient emission reductions.

Acknowledgements. We thank Elisabetta Vignati, Julian Wilson and Philip Stier for making the M7 source code available to us, Sangeeta Sharma (Environment Canada) for providing measurement data for Alert and Joshua Schwarz (NOAA ESRL CSD) for vertical BC data from the HIPPO1 flight campaign. We also thank Rolf Weller (Alfred Wegener Institute for Polar and Marine Research, Germany) and Casper Labuschagne (South African Weather Service) for making BC data from the Neumayer and Cape Point stations available. We acknowledge the NOAA/ESRL/GMD aerosol group, the IMPROVE (http://vista.
cira.colostate.edu/IMPROVE/), EMEP (http://www.emep.int/) and EBAS (http://ebas.nilu.no/Default.aspx) data bases, and Sarah Doherty and colleagues for making the data on BC measurements in Arctic snow publicly available. Thanks to Ragnhild B. Skeie (CICERO) for help with the analysis.

This work was funded by the Norwegian Research Council (project number: 184873/S30, "Unlocking the Arctic Ocean: The climate impact of increased shipping and petroleum activities (ArcAct)").

Edited by: Y. Balkanski

\section{References}

Ackerman, A. S., Toon, O. B., Stevens, D. E., Heymsfield, A. J., Ramanathan, V., and Welton E. J.: Reduction of tropical cloudiness by soot, Science, 288, 1042-1047, 2000.

AMAP: Quinn, P. K., Stohl, A., Arneth, A., Berntsen, T., Burkhart, J. F., Christensen, J., Flanner, M., Kupiainen, K., Lihavainen, H., Shepherd, M., Shevchenko, V., Skov, H., and Vestreng, V.: The Impact of Black Carbon on Arctic Climate, Actic Monitoring and Assessment Programme (AMAP), Oslo, 128 pp., 2011.

Aunan K., Fang J., Hu T., Seip H. M., and Vennemo H.: Climate Change and Air Quality - Measures with Co-Benefits in China. Environ. Sci. Technol., 40, 4822-4829, doi:10.1021/es062994k, 2006.

Ban-Weiss, G., Cao, L., Bala, G., and Caldeira, K.: Dependence of climate forcing and response on the altitude of black carbon aerosols, Clim. Dynam., 1-15, doi:10.1007/s00382-011-1052-y, 2011.

Bauer, S. E., Koch, D., Unger, N., Metzger, S. M., Shindell, D. T., and Streets, D. G.: Nitrate aerosols today and in 2030: a global simulation including aerosols and tropospheric ozone, Atmos. Chem. Phys., 7, 5043-5059, doi:10.5194/acp-7-5043-2007, 2007.

Bauer, S. E., Menon, S., Koch, D., Bond, T. C., and Tsigaridis, K.: A global modeling study on carbonaceous aerosol microphysical characteristics and radiative effects, Atmos. Chem. Phys., 10, 7439-7456, doi:10.5194/acp-10-7439-2010, 2010.

Bellouin, N., Rae, J., Jones, A., Johnson, C., Haywood, J. and Boucher, O.: Aerosol forcing in the Climate Model Intercomparison Project (CMIP5) simulations by HadGEM2-ES and the role of ammonium nitrate, J. Geophys. Res.-Atmos., 116, D20206, doi:10.1029/2011jd016074, 2011.

Berglen, T. F., Berntsen, T. K., Isaksen, I. S. A., and Sundet, J. K.: A global model of the coupled sulfur/oxidant chemistry in the troposphere: The sulfur cycle, J. Geophys. Res.-Atmos., 109, D19310, doi:10.1029/2003jd003948, 2004.

Berntsen, T., Fuglestvedt, J., Myhre, G., Stordal, F., and Berglen T. F.: Abatement of greenhouse gases: Does location matter?, Clim. Change, 74, 377-411, doi:10.1007/s10584-006-0433-4, 2006.

Berntsen T. K. and Isaksen I. S. A.: A global three-dimensional chemical transport model for the troposphere .1. Model description and CO and ozone results, J. Geophys. Res.-Atmos., 102, 21239-21280, doi:10.1029/97jd01140, 1997.

Bice, K., Eil, A., Habib, B., Heijmans, P., Kopp, R., Nogues, J., Norcross, F., Sweitzer-Hamilton, M., and Whitworth, A.: Black carbon: A review and policy recommendations, Princeton Uni- 
versity Woodrow Wilson School of Public and International Affairs, 2009.

Bond T. C., Anderson T. L., and Campbell D.: Calibration and intercomparison of filter-based measurements of visible light absorption by aerosols, Aerosol Sci. Technol., 30, 582-600, doi:10.1080/027868299304435, 1999.

Bond T. C., Streets D. G., Yarber K. F., Nelson S. M., Woo J.-H., and Klimont Z.: A technology-based global inventory of black and organic carbon emissions from combustion, J. Geophys. Res. 109, D14203, doi:10.1029/2003jd003697, 2004.

Bond T. C. and Sun H. L.: Can reducing black carbon emissions counteract global warming?, Environ. Sci. Technol., 39, 59215926, doi:10.1021/es0480421, 2005.

Bond T. C. and Bergstrom R. W.: Light absorption by carbonaceous particles: An investigative review, Aerosol Sci. Technol., 40, 2767, doi:10.1080/02786820500421521, 2006.

Bond T. C., Habib G., and Bergstrom R. W.: Limitations in the enhancement of visible light absorption due to mixing state, J. Geophys. Res.-Atmos., 111, D20211, doi:10.1029/2006jd007315, 2006.

Bond T. C.: Can warming particles enter global climate discussions?, Environ. Res. Lett., 2, 045030, doi:10.1088/17489326/2/4/045030, 2007.

Bond, T. C., Bhardwaj, E., Dong, R., Jogani, R., Jung, S., Roden, C., Streets, D. G. and Trautmann, N. M.: Historical emissions of black and organic carbon aerosol from energy-related combustion, 1850-2000, Global Biogeochem. Cy., 21, GB2018, doi:10.1029/2006gb002840, 2007.

Chung S. H. and Seinfeld J. H.: Global distribution and climate forcing of carbonaceous aerosols, J. Geophys. Res.-Atmos., 107, 4407, doi:10.1029/2001jd001397, 2002.

Chung S. H. and Seinfeld J. H.: Climate response of direct radiative forcing of anthropogenic black carbon, J. Geophys. Res.-Atmos., 110, D11102, doi:10.1029/2004jd005441, 2005.

Clarke A. D. and Noone K. J.: Soot in the Arctic snowpack - A cause for perturbations in radiative-transfer, Atmos. Environ., 19, 2045-2053, doi:10.1016/0004-6981(85)90113-1, 1985.

Cook J. and Highwood E. J.: Climate response to tropospheric absorbing aerosols in an intermediate general-circulation model, Q. J. Roy. Meteorol. Soc., 130, 175-191, doi:10.1256/qj.03.64, 2004.

Cooke W. F., Liousse C., Cachier H., and Feichter J.: Construction of a 1 degrees $\mathrm{x} 1$ degrees fossil fuel emission data set for carbonaceous aerosol and implementation and radiative impact in the ECHAM4 model, J. Geophys. Res.-Atmos., 104, 2213722162, doi:10.1029/1999jd900187, 1999.

Croft, B., Lohmann, U., and von Salzen, K.: Black carbon ageing in the Canadian Centre for Climate modelling and analysis atmospheric general circulation model, Atmos. Chem. Phys., 5, 19311949, doi:10.5194/acp-5-1931-2005, 2005.

Doherty, S. J., Warren, S. G., Grenfell, T. C., Clarke, A. D., and Brandt, R. E.: Light-absorbing impurities in Arctic snow, Atmos. Chem. Phys., 10, 11647-11680, doi:10.5194/acp-1011647-2010, 2010.

Flanner M. G., Zender C. S., Randerson J. T., and Rasch P. J.: Present-day climate forcing and response from black carbon in snow, J. Geophys. Res., 112, D11202, doi:10.1029/2006JD008003, 2007.
Flanner, M. G., Zender, C. S., Hess, P. G., Mahowald, N. M., Painter, T. H., Ramanathan, V., and Rasch, P. J.: Springtime warming and reduced snow cover from carbonaceous particles, Atmos. Chem. Phys., 9, 2481-2497, doi:10.5194/acp-9-24812009, 2009.

Grini, A.: Including the M7 aerosol dynamics model in the global Chemistry Transport Model Oslo CTM2, Report no. 133; ISBN 82-91885-37-0, 2007.

Hansen, J., Sato, M., Ruedy, R., Lacis, A., and Oinas, V.: Global warming in the twenty-first century: An alternative scenario, Proc. Natl. Acad. Sci. USA, 97, 9875-9880, 2000.

Hansen, J. and Nazarenko, L.: Soot climate forcing via snow and ice albedos. PNAS, 101, 423-428, 2003.

Hansen J., Sato M., Ruedy R., Nazarenko L., Lacis A., Schmidt G. A., Russell G., Aleinov I., Bauer M., Bauer S., Bell N., Cairns B., Canuto V., Chandler M., Cheng Y., Del Genio A., Faluvegi G., Fleming E., Friend A., Hall T., Jackman C., Kelley M., Kiang N., Koch D., Lean J., Lerner J., Lo K., Menon S., Miller R., Minnis P., Novakov T., Oinas V., Perlwitz J., Rind D., Romanou A., Shindell D., Stone P., Sun S., Tausnev N., Thresher D., Wielicki B., Wong T., Yao M. and Zhang S.: Efficacy of climate forcings, J. Geophys. Res.-Atmos., 110, D18104, doi:10.1029/2005JD005776, 2005.

Haywood J. M., Roberts D. L., Slingo A., Edwards J. M., and Shine K. P.: General circulation model calculations of the direct radiative forcing by anthropogenic sulfate and fossilfuel soot aerosol, J. Clim., 10, 1562-1577, doi:10.1175/15200442(1997)010<1562:GCMCOT>2.0.CO;2, 1997.

Haywood J. M. and Shine K. P.: Multi-spectral calculations of the direct radiative forcing of tropospheric sulphate and soot aerosols using a column model, Quart. J. Roy. Meteorol. Soc., 123, 19071930, 1997.

Hegg, D. A., Warren, S. G., Grenfell, T. C., Doherty, S. J., Larson, T. V., and Clarke, A. D.: Source Attribution of Black Carbon in Arctic Snow. Environ. Sci. Technol., 43, 4016-4021, doi:10.1021/es803623f, 2009.

Hegg, Dean A., Warren, Stephen G., Grenfell, Thomas C., Sarah J Doherty, and Clarke, Antony D.: Sources of light-absorbing aerosol in arctic snow and their seasonal variation, Atmos. Chem. Phys., 10, 10923-10938, doi:10.5194/acp-10-10923-2010, 2010.

Holtslag A. A. M., Debruijn, E. I. F., and Pan, H. L.: A highresolution air-mass transformation model for short-range weather forecasting, Mon. Weather Rev., 118, 1561-1575, doi:10.1175/1520-0493(1990)118<1561:AHRAMT>2.0.CO;2, 1990.

Hoose C., Kristjansson J. E., Chen J. P., and Hazra A.: A Classical-Theory-Based Parameterization of Heterogeneous Ice Nucleation by Mineral Dust, Soot, and Biological Particles in a Global Climate Model, J. Atmos. Sci., 67, 2483-2503, doi:10.1175/2010jas3425.1, 2010.

Hoyle, C. R., Berntsen, T., Myhre, G., and Isaksen, I. S. A.: Secondary organic aerosol in the global aerosol - chemical transport model Oslo CTM2, Atmos. Chem. Phys., 7, 5675-5694, doi:10.5194/acp-7-5675-2007, 2007.

Jacobson M. Z.: Strong radiative heating due to the mixing state of black carbon in atmospheric aerosols, Nature, 409, 695-697, doi:10.1038/35055518, 2001.

Jacobson M. Z.: Control of fossil-fuel particulate black carbon and organic matter, possibly the most effective method 
of slowing global warming, J. Geophys. Res., 107, 4410, doi:10.1029/2001JD001376, 2002.

Jacobson M. Z.: Climate response of fossil fuel and biofuel soot, accounting for soot's feedback to snow and sea ice albedo and emissivity, J. Geophys. Res.-Atmos., 109, D21201, doi:10.1029/2004jd004945, 2004.

Jacobson M. Z.: Short-term effects of controlling fossil-fuel soot, biofuel soot and gases, and methane on climate, Arctic ice, and air pollution health, J. Geophys. Res.-Atmos., 115, D14209, doi:10.1029/2009jd013795, 2010.

Jaffe, D., Tamura S., and Harris, J.: Seasonal cycle and composition of background fine particles along the west coast of the US, Atmos. Environ., 39, 297-306, doi:10.1016/j.atmonsenv.2004.09.016, 2005.

Johnson, B. T., Shine, K. P., and Forster, P. M.: The semi-direct aerosol effect: Impact of absorbing aerosols on marine stratocumulus, Q. J. Roy. Meterorol. Soc., 130, 1407-1422, 2004.

Koch, D.: Transport and direct radiative forcing of carbonaceous and sulfate aerosols in the GISS GCM, J. Geophys. Res.-Atmos., 106, 20311-20332, 2001.

Koch, D., Bond, T. C., Streets, D., Unger, N., and van der Werf, G. R.: Global impacts of aerosols from particular source regions and sectors, J. Geophys. Res.-Atmos., 112, D02205, doi:10.1029/2005jd007024, 2007.

Koch, D., Schulz, M., Kinne, S., McNaughton, C., Spackman, J. R., Balkanski, Y., Bauer, S., Berntsen, T., Bond, T. C., Boucher, O., Chin, M., Clarke, A., De Luca, N., Dentener, F., Diehl, T., Dubovik, O., Easter, R., Fahey, D. W., Feichter, J., Fillmore, D., Freitag, S., Ghan, S., Ginoux, P., Gong, S., Horowitz, L., Iversen, T., Kirkevåg, A., Klimont, Z., Kondo, Y., Krol, M., Liu, X., Miller, R., Montanaro, V., Moteki, N., Myhre, G., Penner, J. E., Perlwitz, J., Pitari, G., Reddy, S., Sahu, L., Sakamoto, H., Schuster, G., Schwarz, J. P., Seland, Ø., Stier, P., Takegawa, N., Takemura, T., Textor, C., van Aardenne, J. A., and Zhao, Y.: Evaluation of black carbon estimations in global aerosol models, Atmos. Chem. Phys., 9, 9001-9026, doi:10.5194/acp-9-9001-2009, 2009.

Koch, D. and Del Genio, A. D.: Black carbon semi-direct effects on cloud cover: review and synthesis, Atmos. Chem. Phys., 10, 7685-7696, doi:10.5194/acp-10-7685-2010, 2010.

Koch, D., Balkanski, Y., Bauer, S. E., Easter, R. C., Ferrachat, S., Ghan, S. J., Hoose, C., Iversen, T., Kirkevåg, A., Kristjansson, J. E., Liu, X., Lohmann, U., Menon, S., Quaas, J., Schulz, M., Seland, Ø., Takemura, T., and Yan, N.: Soot microphysical effects on liquid clouds, a multi-model investigation, Atmos. Chem. Phys., 11, 1051-1064, doi:10.5194/acp-11-1051-2011, 2011.

Kopp, R. E. and Mauzerall, D. L.: Assessing the climatic benefits of black carbon mitigation, Proc. Natl. Acad. Sci. USA, 107, 11703-11708, doi:10.1073/pnas.0909605107, 2010.

Koren, I., Kaufman, Y. J., Remer, L. A., and Martins, J. V.: Measurement of the effect of Amazon smoke on inhibition of cloud formation, Science, 303, 1342, doi:10.1126/science.1089424, 2004.

Liu, J., Fan, S., Horowitz, L. W., and Levy II, H.: Evaluation of factors controlling long-range transport of black carbon to the Arctic, J. Geophys. Res.-Atmos., 116, D04307, doi:10.1029/2010jd015145, 2011.

Liu, X. H., Penner, J. E., and Wang, M. H.: Influence of anthropogenic sulfate and black carbon on upper tropospheric clouds in the NCAR CAM3 model coupled to the IMPACT global aerosol model, J. Geophys. Res.-Atmos., 114, D03204, doi:10.1029/2008jd010492, 2009.

Massoli, P., Murphy, D. M., Lack, D. A., Baynard, T., Brock, C. A., and Lovejoy, E. R.: Uncertainty in Light Scattering Measurements by TSI Nephelometer: Results from Laboratory Studies and Implications for Ambient Measurements, Aerosol Sci. Technol., 42, 1064-1074, doi:10.1080/02786820903156542, 2009.

Moteki, N., Kondo, Y., Miyazaki, Y., Takegawa, N., Komazaki, Y., Kurata, G., Shirai, T., Blake, D. R., Miyakawa T., and Koike, M.: Evolution of mixing state of black carbon particles: Aircraft measurements over the western Pacific in March 2004. Geophys. Res. Lett., 34, L11803, doi:10.1029/2006g102894, 2007.

Myhre, G., Grini, A., and Metzger, S.: Modelling of nitrate and ammonium-containing aerosols in presence of sea salt, Atmos. Chem. Phys., 6, 4809-4821, doi:10.5194/acp-6-4809-2006, 2006.

Myhre, G., Berglen, T. F., Johnsrud, M., Hoyle, C. R., Berntsen, T. K., Christopher, S. A., Fahey, D. W., Isaksen, I. S. A., Jones, T. A., Kahn, R. A., Loeb, N., Quinn, P., Remer, L., Schwarz, J. P., and Yttri, K. E.: Modelled radiative forcing of the direct aerosol effect with multi-observation evaluation, Atmos. Chem. Phys., 9, 1365-1392, doi:10.5194/acp-9-1365-2009, 2009.

Novakov, T., Menon, S., Kirchstetter, T. W., Koch, D., and Hansen, J. E.: Aerosol organic carbon to black carbon ratios: Analysis of published data and implications for climate forcing, J. Geophys. Res.-Atmos., 110, doi:10.1029/2005jd005977, 2005.

Ohara, T., Akimoto, H., Kurokawa, J., Horii, N., Yamaji, K., Yan, X., and Hayasaka, T. An Asian emission inventory of anthropogenic emission sources for the period 1980-2020, Atmos. Chem. Phys., 7, 4419-4444, doi:10.5194/acp-7-4419-2007, 2007.

Oshima, N., Koike, M., Zhang, Y., Kondo, Y., Moteki, N., Takegawa, N., and Miyazaki, Y.: Aging of black carbon in outflow from anthropogenic sources using a mixing state resolved model: Model development and evaluation, J. Geophys. Res.Atmos., 114, D06210, doi:10.1029/2008jd010680, 2009.

Penner, J. E., Chen, Y., Wang, M., and Liu, X.: Possible influence of anthropogenic aerosols on cirrus clouds and anthropogenic forcing, Atmos. Chem. Phys., 9, 879-896, doi:10.5194/acp-9-8792009, 2009.

Prather M. J.: Numerical advection by conservation of 2ndorder moments, J. Geophys. Res.-Atmos., 91, 6671-6681, doi:10.1029/JD091iD06p06671, 1986.

Quinn, P. K., Bates, T. S., Baum, E., Doubleday, N., Fiore, A. M., Flanner, M., Fridlind, A., Garrett, T. J., Koch, D., Menon, S., Shindell, D., Stohl, A., and Warren, S. G.: Short-lived pollutants in the Arctic: their climate impact and possible mitigation strategies, Atmos. Chem. Phys., 8, 1723-1735, doi:10.5194/acp8-1723-2008, 2008.

Reddy M. S. and Boucher O.: Climate impact of black carbon emitted from energy consumption in the world's regions, Geophys. Res. Lett., 34, L11802, doi:10.1029/2006g1028904, 2007.

Riemer N., West M., Zaveri R. A., and Easter R. C.: Simulating the evolution of soot mixing state with a particleresolved aerosol model, J. Geophys. Res.-Atmos., 114, D09202, doi:10.1029/2008jd011073, 2009.

Riemer, N., West, M., Zaveri, R., and Easter, R.: Estimating black carbon aging time-scales with a particle-resolved aerosol model, J. Aerosol Sci., 41, 143-158, doi:10.1016/j.jaerosci.2009.08.009, 
2010.

Rypdal K., Rive N., Berntsen T., Fagerli H., Klimont Z., Mideksa T. K. and Fuglestvedt J. S.: Climate and air quality-driven scenarios of ozone and aerosol precursor abatement, Environ. Sci. Pol., 12, 855-869, doi:10.1016/j.envsci.2009.08.002, 2009a..

Rypdal, K., Rive, N., Berntsen, T. K., Klimont, Z., Mideksa, T. K., Myhre, G. and Skeie, R. B.: Costs and global impacts of black carbon abatement strategies. Tellus B - Chem. Phys. Meteorol., 61, 625-641, doi:10.1111/j.1600-0889.2009.00430.x, 2009b.

Samset, B. H. and Myhre, G.: Vertical dependence of black carbon, sulphate and biomass burning aerosol radiative forcing. Geophys. Res. Lett., 38, L24802, doi:10.1029/2011GL049697, 2011.

Satheesh, S. K.: Letter to the Editor Aerosol radiative forcing over land: effect of surface and cloud reflection, Ann. Geophys., 20, 2105-2109, doi:10.5194/angeo-20-2105-2002, 2002.

Schulz, M., Textor, C., Kinne, S., Balkanski, Y., Bauer, S., Berntsen, T., Berglen, T., Boucher, O., Dentener, F., Guibert, S., Isaksen, I. S. A., Iversen, T., Koch, D., Kirkevåg, A., Liu, X., Montanaro, V., Myhre, G., Penner, J. E., Pitari, G., Reddy, S., Seland, $\varnothing$. ., Stier, P., and Takemura, T.: Radiative forcing by aerosols as derived from the AeroCom present-day and pre-industrial simulations, Atmos. Chem. Phys., 6, 5225-5246, doi:10.5194/acp-65225-2006, 2006.

Schwarz J. P., Spackman J. R., Fahey D. W., Gao R. S., Lohmann U., Stier P., Watts L. A., Thomson D. S., Lack D. A., Pfister L., Mahoney M. J., Baumgardner D., Wilson J. C., and Reeves J. M.: Coatings and their enhancement of black carbon light absorption in the tropical atmosphere, J. Geophys. Res.-Atmos., 113, D03203, doi:10.1029/2007jd009042, 2008..

Schwarz, J. P., Spackman, J. R., Gao, R. S., Perring, A. E., Cross, E., Onasch, T. B., Ahern, A., Wrobel, W., Davidovits, P., Olfert, J., Dubey, M. K., Mazzoleni, C., and Fahey, D. W.: The Detection Efficiency of the Single Particle Soot Photometer. Aerosol Sci. Technol., 44, 612-628, doi:10.1080/02786826.2010.481298, 2010a..

Schwarz, J. P., Spackman, J. R., Gao, R. S., Watts, L. A., Stier, P., Schulz, M., Davis, S. M., Wofsy, S. C., and Fahey, D. W.: Global-scale black carbon profiles observed in the remote atmosphere and compared to models, Geophys. Res. Lett. 37, L18812, doi:10.1029/2010g1044372, 2010b.

Sciare, J., Favez, O. R. S.-E., Oikonomou, K., and Cachier, H.: Long-term observations of carbonaceous aerosols in the Austral Ocean atmosphere: Evidence of a biogenic marine organic source, J. Geophys. Res., 114, D15302, doi:10.1029/2009JD011998, 2009.

Seinfeld, J. H. and Pandis, S. N.: Atmospheric Chemistry and Physics - From Air Pollution to Climate Change (2nd Edition), John Wiley \& Sons., 1225 pp., online available at: http://www.knovel.com/web/portal/browse/display? _EXT_KNOVEL_DISPLAY_bookid=2126\&VerticalID=0, 2006.

Shindell, D. and Faluvegi, G.: Climate response to regional radiative forcing during the twentieth century, Nature Geosci., 2, 294-300, doi:10.1038/ngeo473, 2009.

Shindell, D. T., Chin, M., Dentener, F., Doherty, R. M., Faluvegi, G., Fiore, A. M., Hess, P., Koch, D. M., MacKenzie, I. A., Sanderson, M. G., Schultz, M. G., Schulz, M., Stevenson, D. S., Teich, H., Textor, C., Wild, O., Bergmann, D. J., Bey, I., Bian, H., Cuvelier, C., Duncan, B. N., Folberth, G., Horowitz, L. W., Jonson, J., Kaminski, J. W., Marmer, E., Park, R., Pringle, K. J., Schroeder,
S., Szopa, S., Takemura, T., Zeng, G., Keating, T. J., and Zuber, A.: A multi-model assessment of pollution transport to the Arctic, Atmos. Chem. Phys., 8, 5353-5372, doi:10.5194/acp-85353-2008, 2008.

Shiraiwa, M., Kondo, Y., Moteki, N., Takegawa, N., Miyazaki, Y. and Blake, D. R.: Evolution of mixing state of black carbon in polluted air from Tokyo, Geophys. Res. Lett., 34, L16803, doi:10.1029/2007g1029819, 2007.

Skeie, R. B., Berntsen, T., Myhre, G., Pedersen, C. A., Ström, J., Gerland, S., and Ogren, J. A.: Black carbon in the atmosphere and snow, from pre-industrial times until present, Atmos. Chem. Phys., 11, 6809-6836, doi:10.5194/acp-11-6809-2011, 2011.

Spackman, J. R., Gao, R. S., Neff, W. D., Schwarz, J. P., Watts, L. A., Fahey, D. W., Holloway, J. S., Ryerson, T. B., Peischl, J., and Brock, C. A.: Aircraft observations of enhancement and depletion of black carbon mass in the springtime Arctic, Atmos. Chem. Phys., 10, 9667-9680, doi:10.5194/acp-10-9667-2010, 2010.

Spackman, J. R., Gao, R. S., Schwarz, J. P., Watts, L. A., Fahey, D. W., Pfister, L. and Bui, T. P.: Seasonal variability of black carbon mass in the tropical tropopause layer. Geophys. Res. Lett., 38, L09803, doi:10.1029/2010g1046343, 2011.

Stohl, A.: Characteristics of atmospheric transport into the Arctic troposphere, J. Geophys. Res.-Atmos., 111, D11306, doi:10.1029/2005jd006888, 2006.

Stohl, A., Berg, T., Burkhart, J. F., Fjǽraa, A. M., Forster, C., Herber, A., Hov, Ø., Lunder, C., McMillan, W. W., Oltmans, S., Shiobara, M., Simpson, D., Solberg, S., Stebel, K., Ström, J., Tørseth, K., Treffeisen, R., Virkkunen, K., and Yttri, K. E.: Arctic smoke - record high air pollution levels in the European Arctic due to agricultural fires in Eastern Europe in spring 2006, Atmos. Chem. Phys., 7, 511-534, doi:10.5194/acp-7-511-2007, 2007.

Tiedtke M. A comprehensive mass flux scheme for cumulus parameterization in large-scale models, Mon. Weather Rev., 117, 1779-1800, doi:10.1175/15200493(1989)117<1779:ACMFSF>2.0.CO;2, 1989. ..

van der Werf, G. R., Randerson, J. T., Giglio, L., Collatz, G. J., Kasibhatla, P. S., and Arellano Jr., A. F.: Interannual variability in global biomass burning emissions from 1997 to 2004, Atmos. Chem. Phys., 6, 3423-3441, doi:10.5194/acp-6-3423-2006, 2006.

Vignati, E., Wilson, J. and Stier, P.: M7: An efficient sizeresolved aerosol microphysics module for large-scale aerosol transport models, J. Geophys. Res.-Atmos., 109, D22202, doi:10.1029/2003jd004485, 2004..

Vignati, E., Karl, M., Krol, M., Wilson, J., Stier, P., and Cavalli, F.: Sources of uncertainties in modelling black carbon at the global scale, Atmos. Chem. Phys., 10, 2595-2611, doi:10.5194/acp-102595-2010, 2010.

Warren S. G. and Wiscombe W. J.: A model for the spectral albedo of snow. II: Snow containing atmospheric aerosols, J. Atmos. Sci., 37, 2734-2745, 1980 .

Yttri, K. E., Aas, W., Bjerke, A., Cape, J. N., Cavalli, F., Ceburnis, D., Dye, C., Emblico, L., Facchini, M. C., Forster, C., Hanssen, J. E., Hansson, H. C., Jennings, S. G., Maenhaut, W., Putaud, J. P., and Tørseth, K.: Elemental and organic carbon in $\mathrm{PM}_{10}$ : a one year measurement campaign within the European Monitoring and Evaluation Programme EMEP, Atmos. Chem. Phys., 7, 5711-5725, doi:10.5194/acp-7-5711-2007, 2007. 
Zhang, X. Y., Wang, Y. Q., Zhang, X. C., Guo, W., and Gong, S. L.: Carbonaceous aerosol composition over various regions of China during 2006, J. Geophys. Res.-Atmos., 113, D14111, doi:10.1029/2007jd009525, 2008.. 